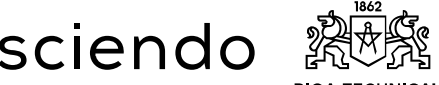 RIGA TECHNICAL
UNIVERSITY}

ISSN 2256-0394 (online)

ISSN 2256-0386 (print)

2018, 32, 182-194

doi: 10.2478/eb-2018-0015

https://content.sciendo.com/view/journals/eb/eb-overview.xml

\title{
BIBLIOMETRIC ANALYSIS OF FINANCIAL RISK ASSESSMENT IN BALTIC COUNTRIES
}

\author{
Natalia SCACUN ${ }^{1}$, Irina VORONOVA ${ }^{2}$ \\ ${ }^{1,2}$ Riga Technical University, Riga, Latvia \\ Corresponding author's e-mail: natalia.scacun@edu.rtu.lv
}

\begin{abstract}
The article represents the bibliometric analysis of risk assessment in Baltic countries relying on scientific database. The purpose of this analysis is to study trends and development of scientific research when evaluating financial risks as well as reveal resources with high impact to apply content analysis that could be used for future research on the topic. The applied investigation methods were chosen based on the analysis of existing scientometric data: the number and dynamics of published documents; their subject area and type; territory/country; source title; affiliation; authors; h-index; citation overview followed by search results as well as adopting search references to reveal the used and cited documents. The authors also present the applied deduction of trends between enterprise death rate in Latvia, Lithuania, and Estonia and the number of documents in the referenced period. This study demonstrates that the amount of research increased significantly when countries face rises in enterprise death rates.
\end{abstract}

Keywords: Baltic region, bibliometric analysis, financial risk assessment, enterprise death rate.

JEL Classification: G00, G33, B26, C53

\section{INTRODUCTION}

Humanity has tried to accumulate knowledge from the early times. In the period of Old Kingdom, "houses of life" emerged, containing libraries, archives, chronicles, and texts of various content. Nowadays, with an increasing interest in automatization called the Internet of Things (Mishra et al, 2016, p. 1332), achieving integration to obtain the picture with current needs is a vital part of helping to generalize and systematize accumulated knowledge and experience. Study term "bibliometric" that nowadays plays a major role in business intelligence and analytics (BI\&A) among researchers and practitioners, both evaluating trend data and identifying main focuses to make a decision, firstly has been used by Fairthorne (1969) and Pritchard (1969). Watts and Porter (1997) define bibliometric analysis as "innovation forecasting" (p. 17). The authors of the present paper agree with this statement as e-research becomes more popular every year. This evidence could be supported by the fact that nowadays libraries are available not only with a sense of physical touching of books, but using online databases. The authors assume that information technology specialists could invent forecasting trends by using concrete online databases. There is literature of bibliometric analysis on methods 
for evaluating financial risks, primarily insolvency enterprises. These works are represented by Silva, Kimura and Sobreiro (2017), by Chang and Ho (2010), by Chen, Chiang and Storey (2012), and by others. In this article, the authors investigate financial risk assessment based on non-financial markets using bibliometric analysis. For this purpose, keywords connected to risk assessment were analyzed, namely, risk model, risk assessment, risk management, risk analysis, risk evaluation, bankruptcy, insolvency, failure, solvency, creditworthiness, credit risk, credit rating, credit scoring. The analyzed geographic area was limited to the Baltic region - Latvia, Estonia, and Lithuania - to show the structure of scientific work in these countries and confirm or deny the results value when representing the structure of science. The reference period chosen for analysis is 2000-2017. The authors do not limit the search to 2016 as in 2017 valuable articles that rely on updated information were analyzed, therefore new trends could appear.

The aim of the paper is to evaluate the research performance of financial risk assessment in the Baltic region using bibliometric analytical parameters, to investigate trends in various disciplines as well as to contribute by discovering scientific directions to view developments in science. The subject of the study is bibliometric analysis; the object of the study is financial risk assessment of nonfinance markets in Baltic countries. To achieve the goals, the following tasks were selected: selection of the scientific database; collecting information from chosen scientific database; data synthetic analytical processing; primary data processing; statistical data application; deduction of statistical parameters and establishing relationships between indicators, and obtaining a conclusion. Moreover, the authors propose three research hypotheses: firstly, the bibliometric tool is effective to monitor the dynamics of science by research field; secondly, the number of documents published in a certain country depends on the economic situation; and, thirdly, the risk of the death of companies decreases during macroeconomic expansion.

The novelty of the approach lies in the fact that data for analysis is generated in an automated manner by scientific database and additional visualization software, detecting the most cited publications/articles, consequently, detecting the resources that make an impact.

\section{METHODOLOGY OF RESEARCH}

Selection of the scientific database and collecting the information about publications is the first stage of bibliometric analysis. Each scientific database is unique because resources may vary and search results could be indexed in different times that may impact accuracy of the investigation.

Synthetic analytical processing is closely related to the quality of selected documents, mainly considering the investigation topic. The authors obtained bibliometric data using two scientific online database libraries: Scopus and Web of Science. The reasons for choosing these libraries were, firstly, that both are recognized and reliable databases, secondly, the existence of an optional menu for 
choosing countries to limit search to the Baltic region and possibilities of various data export formats.

The next step of the investigation is primary data processing where the extracted data quality is represented by the filters used, as well as statistical data application. Qualitative field research were obtained by searching the following fields within a record: title; abstract; author keywords, then followed by deduction of statistical parameters and establishing relationships between indicators. The last stage consists of putting forward the hypothesis to conclude if it was proved or not. The described applied methodology of bibliometric financial risk assessment shown in Fig. 1.

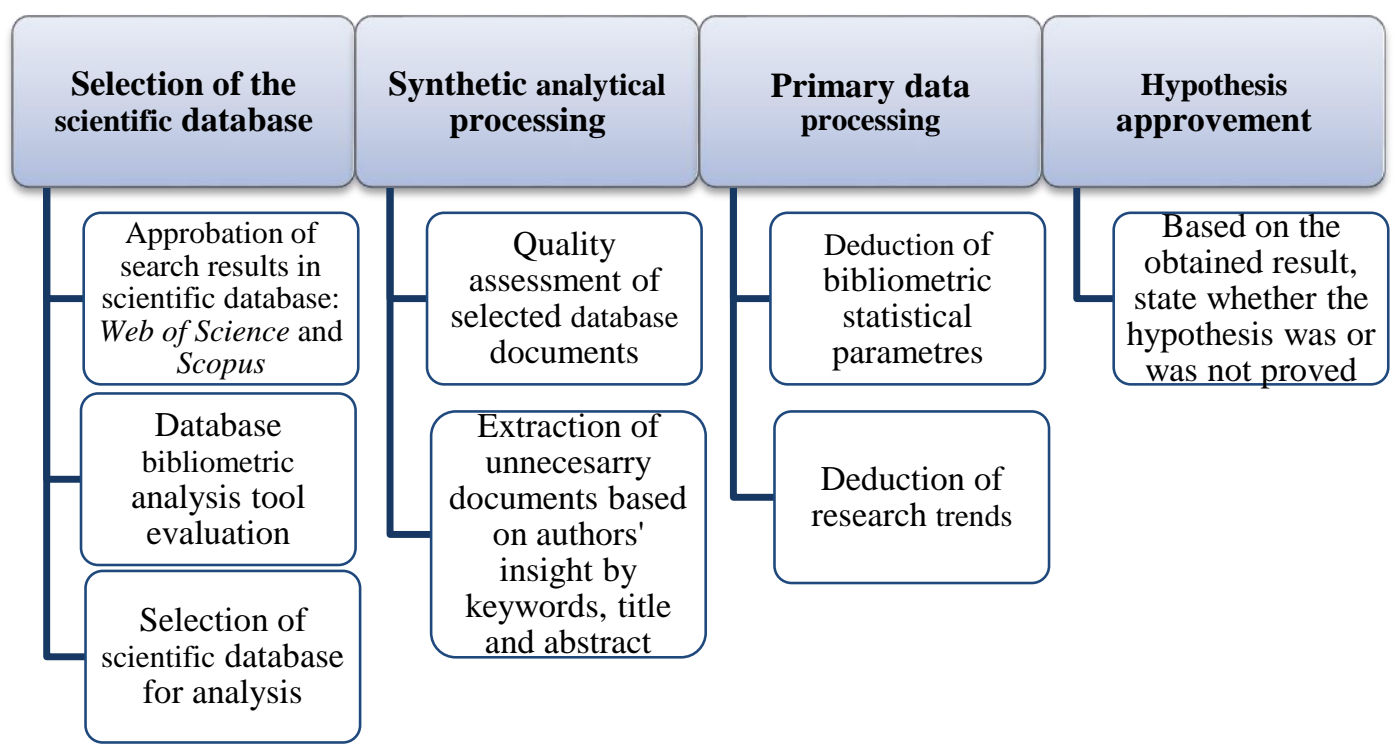

Fig. 1. Research methodology.

\section{FINDINGS/RESULTS}

Collecting database information in September 2017, the authors' aim was to quantitatively compare the data received from Scopus and Web of Science. As presented in Table 1, general searches were deducted by keywords, namely, risk model, risk assessment, risk management, risk analysis, risk evaluation, bankruptcy, insolvency, failure, solvency, creditworthiness, credit risk, credit rating, and credit scoring. Scopus showed more results both by all searches as well as when limiting the geographical region to Baltic countries. To eliminate findings of unnecessary data, the authors applied filters defining the area of the research. In the case of Scopus, the selected area comprised Business, Management and Accounting; and Economics, Econometrics and Finance. In the case of Web of Science, the selected area comprised Economics, Business, Management, Business Finance. It is noteworthy that the article could be attributed to several areas: Engineering, Social Sciences, Computer Sciences, and Mathematics. According to the Table 1, Web of Science showed 13 results more than Scopus when the area was defined. 
Table 1. Search results in Scopus and Web of Science

\begin{tabular}{|c|c|c|}
\hline Criteria & Scopus & Web of Science \\
\hline All searches & $3,587,115$ & 879,869 \\
\hline Baltic countries & 6,962 & 1,954 \\
\hline Defining area & 253 & 266 \\
\hline
\end{tabular}

Analyzing the final results with defined area by source title from two online libraries, results showed that only 95 documents were duplicated; therefore, it can be summarized that 62\% (Scopus), 64\% (Web of Science) are with different documents. This fact serves as evidence that bibliometric survey should be based on data within one library.

While investigating bibliometric software analytical tools of online libraries, the authors concluded that it is wiser to use the original Scopus library capabilities and parameters for facilitating accurate results as Scopus has a wider online analysis application than Web of Science; therefore, the main tool that has been used for analysis is Scopus. For facilitating data accuracy, the authors investigated the abstract title, excluding though authors' insight about the articles that are not related to the investigation topic. As a result, 91 document results from Scopus that matches the research goal were chosen for analysis.

According to the search, in 2000-2004, no scientific documents were published. This fact indicates that authors' activity in Baltic countries began in 2005 in Lithuania. For the reader's convenience, in Fig. 2, authors used acronyms at the end of the word, namely, $\mathrm{d}$ - number of documents; $\mathrm{e}$ - enterprise death rate.

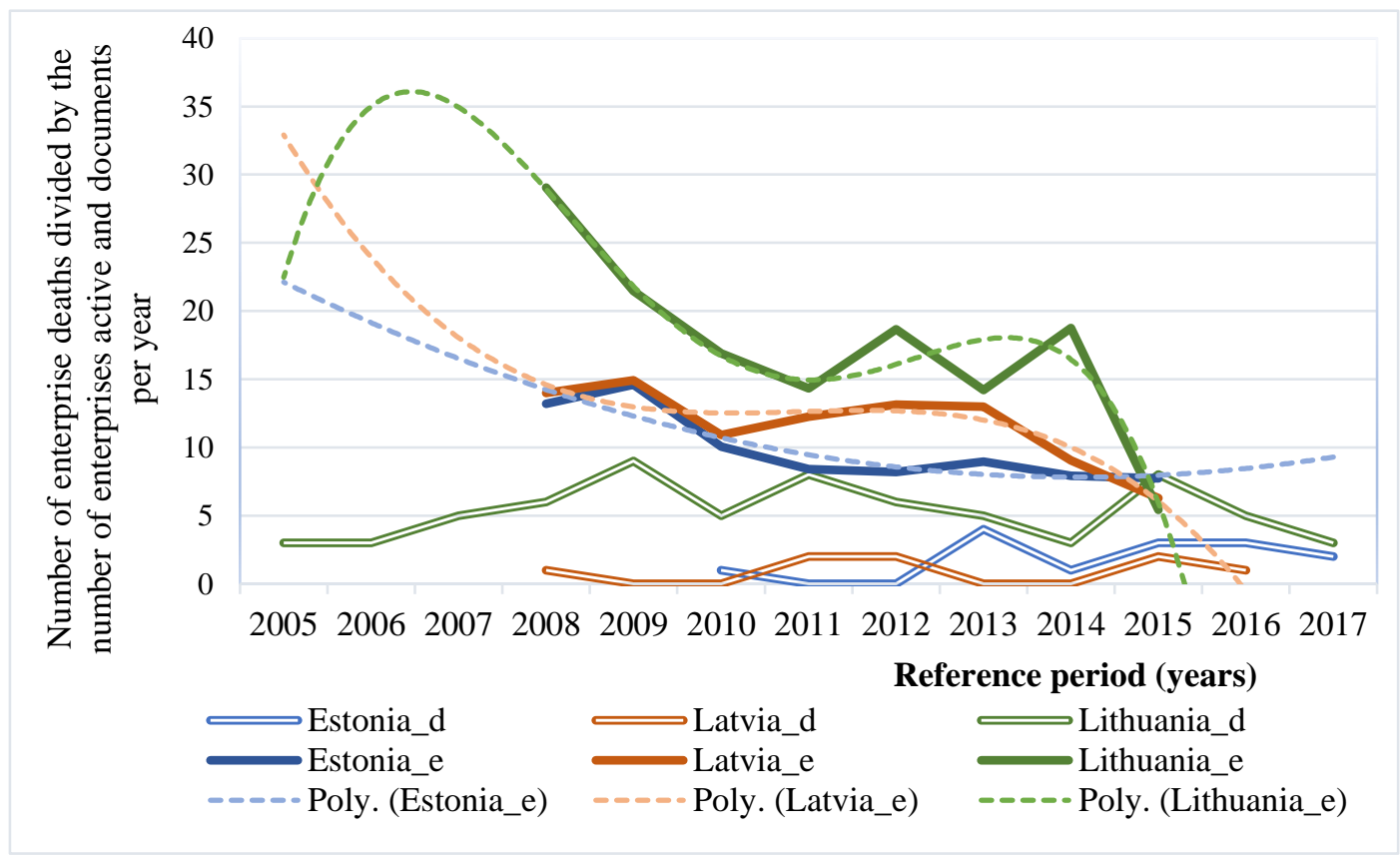

Fig. 2. Relation of documents per year to the number of enterprise deaths in the reference period divided by the number of enterprises active in 2005-2017

(Eurostat, 2017). 
According to Fig. 2, based on the selected search, documents started to appear in 2005 in Lithuania; three years later, documents appeared from Latvia; and in 2010, documents could be found from Estonia. Searched data dynamics is interesting; therefore, the pattern of how bankrupt companies affects the number of publications from Latvia, Lithuania and Estonia was analyzed. For this purpose, the number of documents by the country as well as the death rate were selected and applied as a graph: the number of enterprise deaths in the reference period $(t)$ was divided by the number of enterprises active in $t$ from the Eurostat's statistical database. As enterprise death rates were available only for the period of 2008-2015, trend function was applied in Fig. 2 to show the changes. It can be assumed that death indicator represents valuable data as it considers business demography (Box, 2008). Moreover, based on the graph in Fig. 2, a pattern can be seen that the risk of the death of companies decreased during macroeconomic expansion (Partridge \& Rickman, 2002). The global economic crisis started in 2008; from 2009 until 2015, a recession for Baltic countries could be seen, consequently, not reaching/exceeding the 2009 death rates, which proves the pattern.

In the case of neglecting financial welfare diagnosis, Tatelbaum (2014) found that it might lead the company to bankruptcy as well as cause stakeholders' domino effect. According to Fig. 2, the death rate of enterprises in Baltic countries exceeds active enterprises, which negatively affects economic indicators. Lithuania had the highest death rates until 2015, relatively levelled off with other Baltic countries, followed by Latvia and then Estonia. It is important to note that publishing dynamics of documents is closely related to enterprise death rates by reference period. In the case of Lithuania, ascending dynamics can be seen from 2005 to 2009, which is mostly connected to the global economic crisis, namely, preconditions for companies' bankruptcy and the increasing interest in financial risk assessment.

Documents matching search fields for Latvia started to appear from 2008, for Estonia - 2010. In 2008 - 2009 in Latvia from Fig. 2 can be seen a decline in the number of documents as well as decrease in enterprise death rate. Nonetheless, when indicator started to increase in 2010 - 2013, the number of documents respectively increased. It can be seen from Fig. 2 that in the case of Estonia, the number of documents increased/decreased the same way as applied indicators did. For a higher interpreted data accuracy, it would be wise to analyze and use additional libraries to facilitate greater amount of the search documents by research field. Within the framework of the study were analyzed 91 documents. Lithuania followed by search data has $76 \%$ of all documents; Estonia - 15\%; Latvia $-9 \%$. The results suggest that Lithuania had the highest number of search documents because there were more enterprise death rate difficulties than in Latvia and Estonia.

Fig. 3 demonstrates that selected search documents are classified not only in the focused areas (for instance, Business, Management and Accounting; Economics, Econometrics and Finance), but the same documents can also be found under Engineering, Social Sciences, Decision Sciences, Mathematics, and Computer Science, which shows applicability of the study in different areas. 


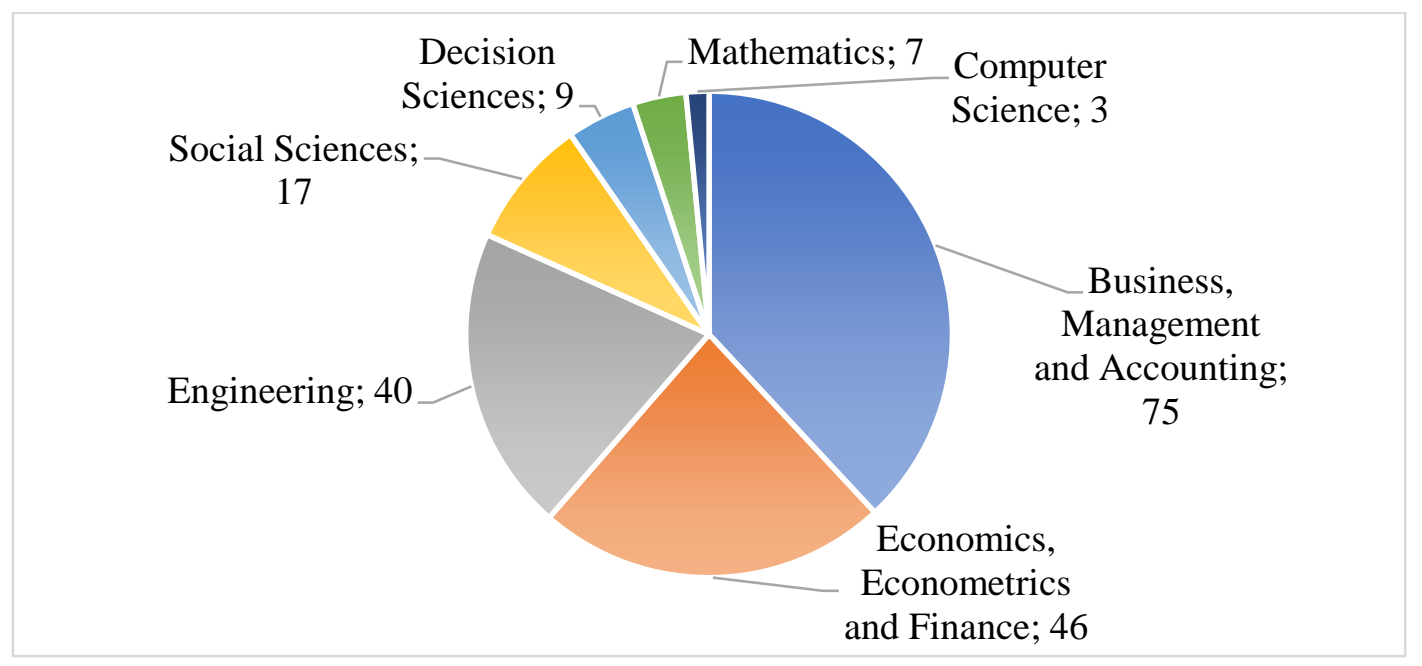

Fig. 3. Number of documents by subject area.

This could be explained by the condition that nowadays many scientific research fields are closely connected with various areas due to process integration, because the solving of complex and global problems requires investigations in different science fields, using the intellectual potential of science and creating solutions for the initial problems.

According to Fig. 4, the majority of documents are published in Business: Theory and Practice (21), Engineering Economics (15), Transformations in Business and Economics (12), International Journal of Strategic Property Management (5), whereas the number of other sources of documents is relatively small (from 3 to 1 ).

When analysing documents per year by the source based on the graph in Fig.4, in 2009, 2011 and 2015, three documents were published in Engineering Economics, and in 2013 and 2015, three articles were published in Business: Theory and Practice.

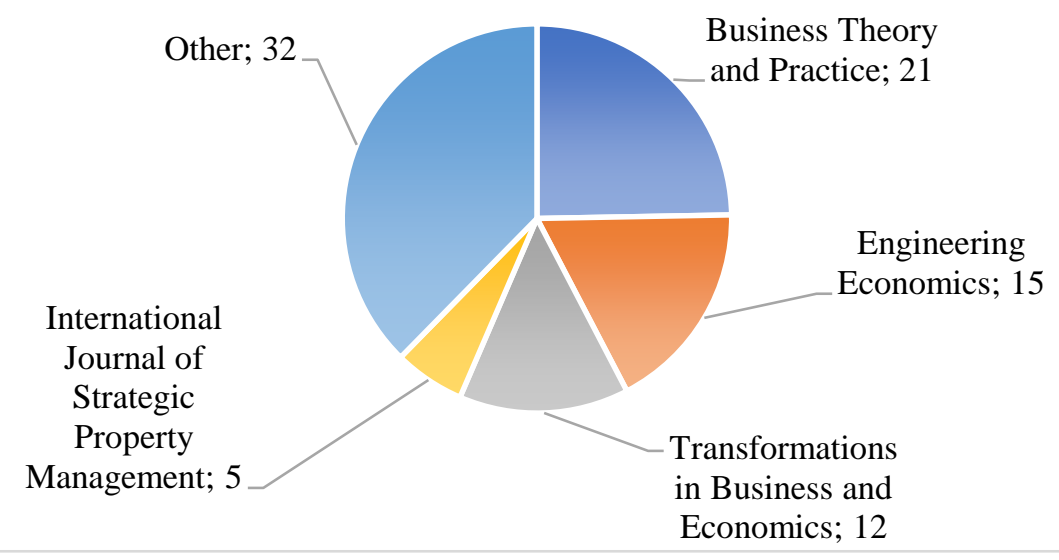

Fig. 4. Documents by the source title. 
According to the searched documents by the author's/co-author's name in Fig. 5, Lukason O. has six documents, Mileris R. has five documents, Aniunas P., Boguslauskas V., Danenas P., Garsva G. and Voronova I. have four documents, and other authors' documents vary from three to one. When evaluating articles subject area by authors, documents of Lukason O. (Estonia; h-index: 3) are related to the occurrence and connections of various firm failures such as exporting, manufacturing, small.; research papers of Mileris R. (Lithuania; h-index: 5), Boguslauskas V. (Lithuania; h-index: 6), Danenas P. (Lithuania; h-index: 6), and Garsva G. (Lithuania; h-index: 8) are devoted to portfolio credit risk estimation and management issues; papers of Aniunas P. (Lithuania; h-index: 2) deal with the liquidity risk management and portfolio management topics; and research papers of Voronova I. (Latvia; h-index: 1) consider the assessment of insolvency risk management.

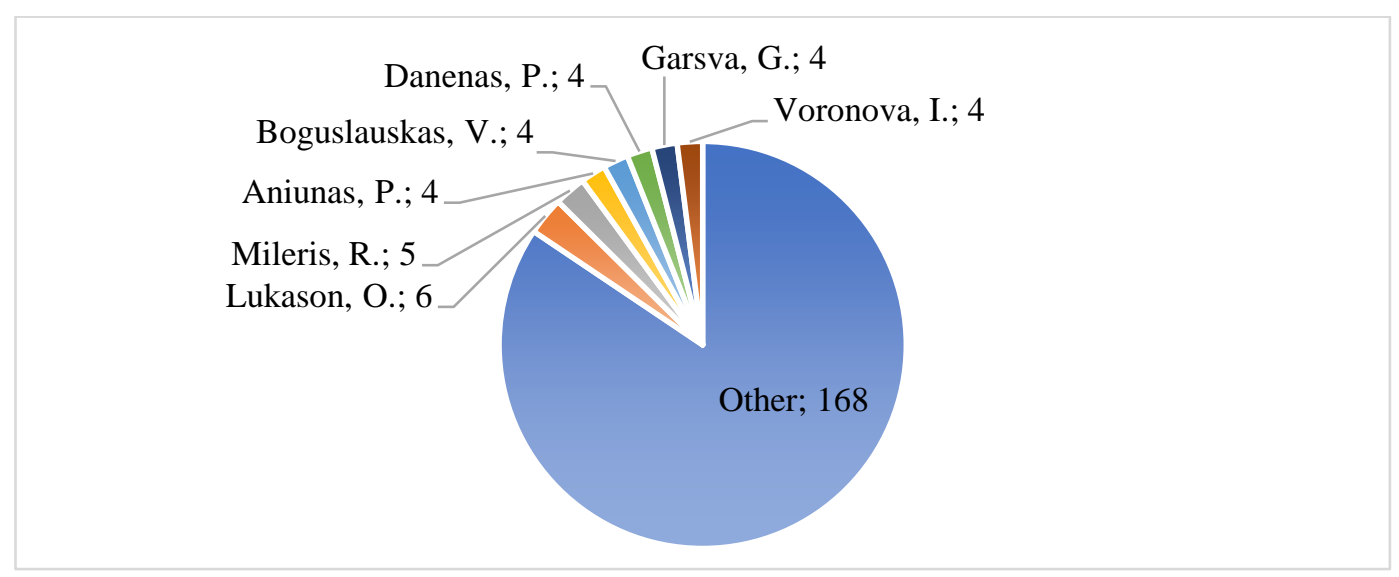

Fig. 5. Documents by the author's (co-author's) name.

Fig. 6 illustrates that the majority of documents are from Vilnius University (24), Vilnius Gediminas Technical University (21), Kaunas University of Technology (18), University of Tartu (7), Riga Technical University (6), Tallinn University of Technology (4), and University of Latvia (3); other organizations are mentioned twice or once.

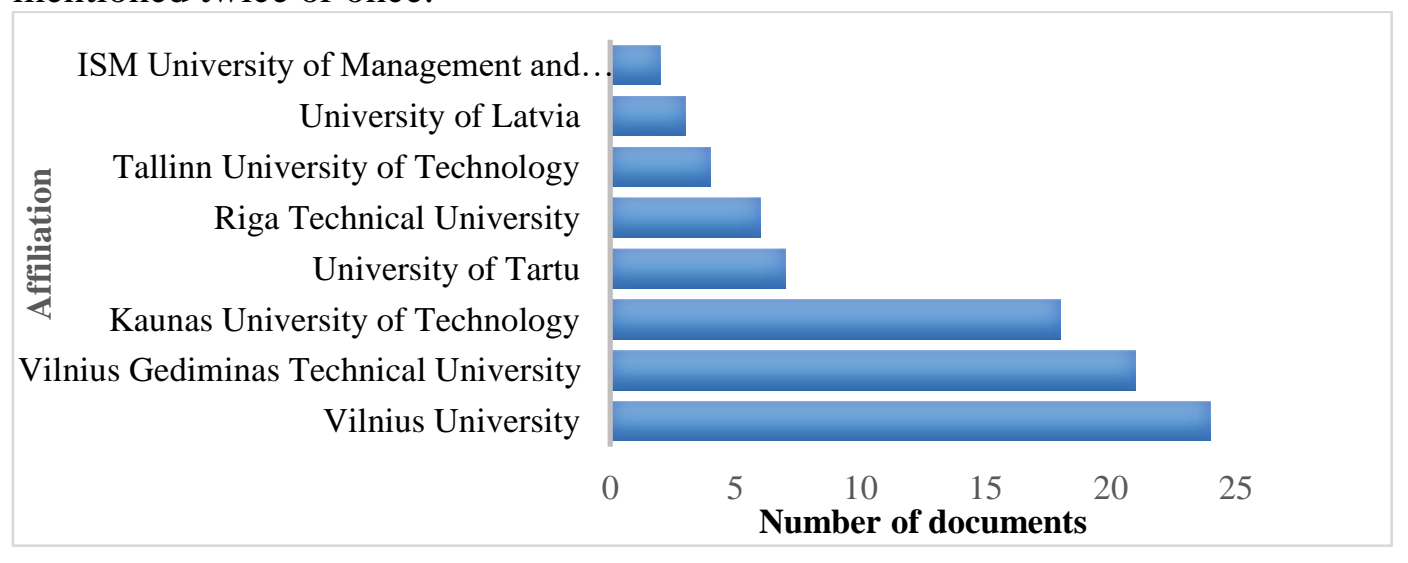

Fig. 6. Documents by affiliation. 
It is interesting to note that the majority of documents were articles (86.8\%), followed by conference papers $(9.9 \%)$, reviews $(2.2 \%)$, and book chapters $(1.1 \%)$.

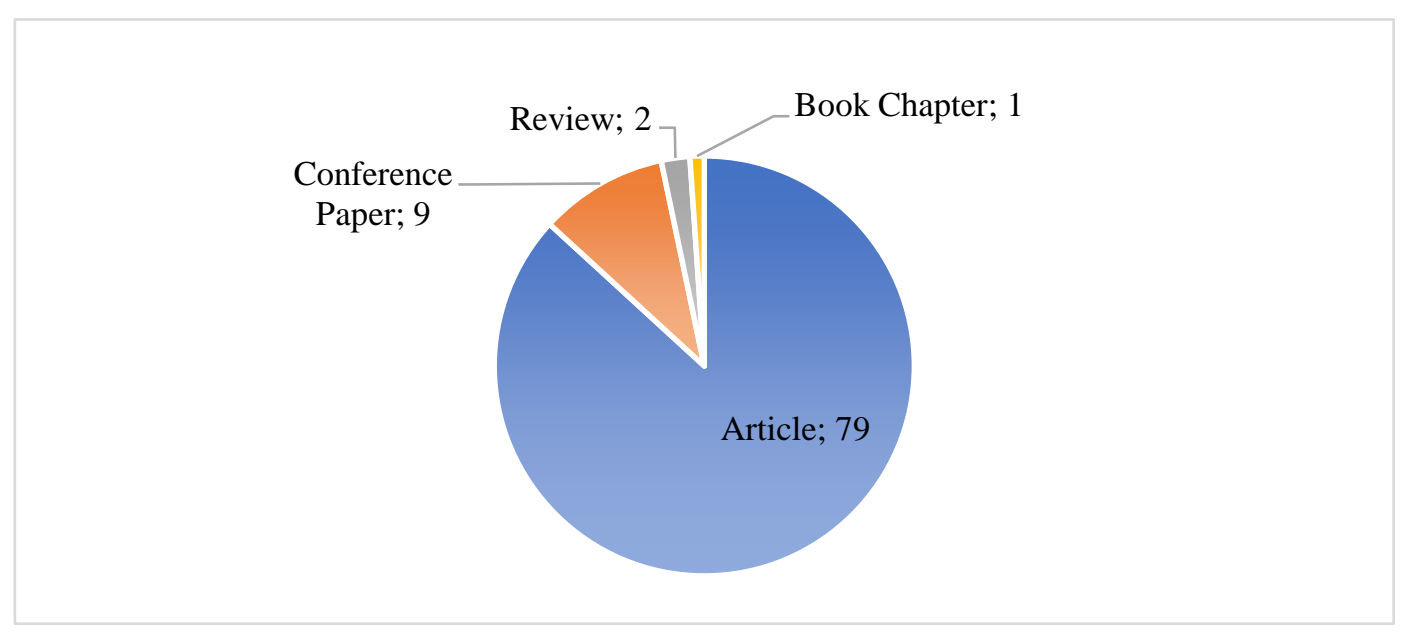

Fig. 7. Documents by type.

Growth dynamics of citations shows the relevance of the research field (Bornmann \& Daniel, 2008). Since 2013, an increase was observed in the number of citations: 22 citations in 2013, 33 citations both in 2014 and 2015, 38 citations in 2016, and 51 citation in 2017.

By selected search based on Fig. 8, documents were cited 337 times with h-index $=10$. H-graph (Elsevier, 2017) is one way of comparing and displaying the productivity and impact of documents. According to Web of Science Core Collection Help (2017), the graph shows a 45-degree line, which models a 1:1 relationship $=$ between the published articles and those being cited. An author's publishing history is mapped out on this graph, beginning with publication from the highest number of citations to the lowest one.

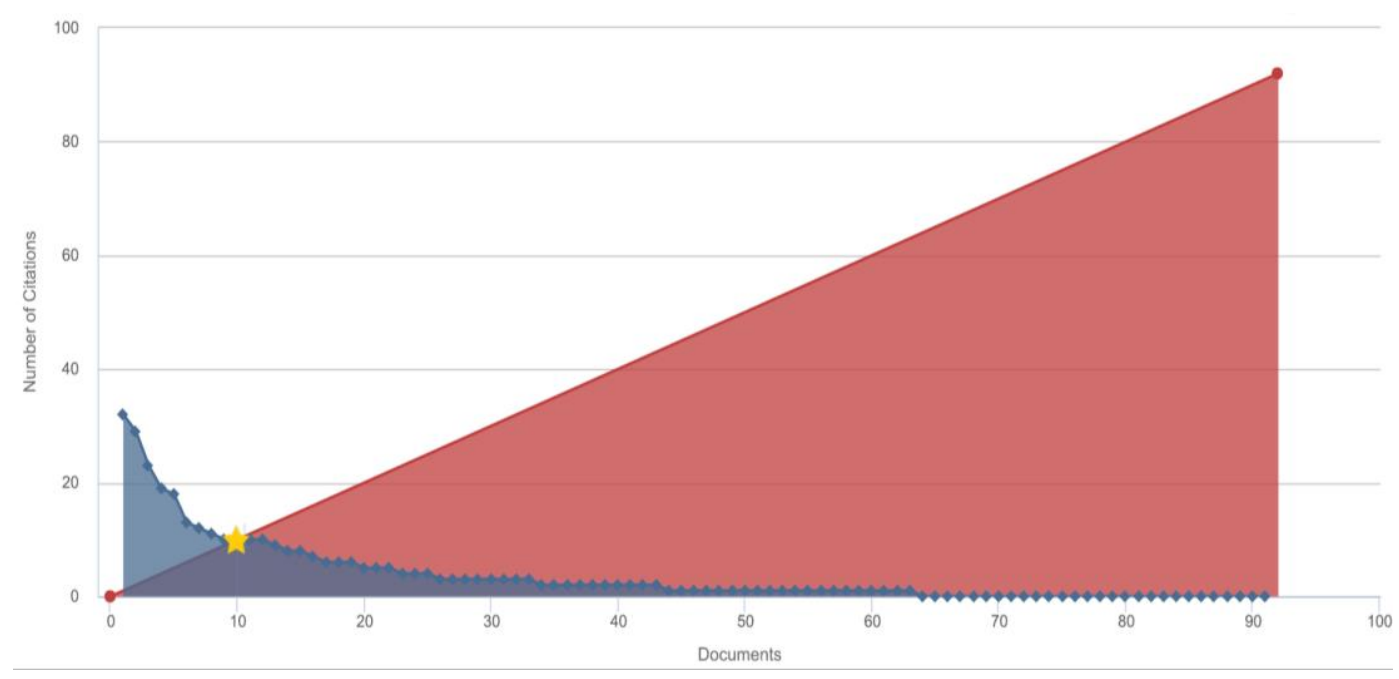

Fig. 8. Documents' h-index (Scopus h-chart). 
Table 2 provides data of 10 most cited documents. It is seen that articles with higher impact are represented by Lithuania, which can be explained by the high enterprise death index in Lithuania, therefore scientific work could be found valuable to prevent worse situation.

Table 2. Most cited documents (top-10)

\begin{tabular}{|c|c|c|c|c|}
\hline Title & Authors & Year & Cited by & Country \\
\hline $\begin{array}{l}\text { Assessing the financial state of } \\
\text { construction enterprises }\end{array}$ & $\begin{array}{l}\text { Ginevičius, R., } \\
\text { Podvezko, V. }\end{array}$ & 2006 & 32 & Lithuania \\
\hline $\begin{array}{l}\text { Tail behavior of random sums } \\
\text { under consistent variation with } \\
\text { applications to the compound } \\
\text { renewal risk model }\end{array}$ & $\begin{array}{l}\text { Aleškevičiene, A., } \\
\text { Leipus, R., Šiaulys, J. }\end{array}$ & 2008 & 29 & Lithuania \\
\hline $\begin{array}{l}\text { Rating methodology for real estate } \\
\text { markets - Poland case study }\end{array}$ & $\begin{array}{l}\text { Renigier-Biłozor, M., } \\
\text { Wisniewski, R., } \\
\text { Kaklauskas, A., } \\
\text { Biłozor, A. }\end{array}$ & 2014 & 23 & Lithuania \\
\hline $\begin{array}{l}\text { Asymptotic behaviour of the finite- } \\
\text { time ruin probability under } \\
\text { subexponential claim sizes }\end{array}$ & Leipus, R., Šiaulys, J. & 2007 & 19 & Lithuania \\
\hline $\begin{array}{l}\text { Support vector machines and their } \\
\text { application in credit risk evaluation } \\
\text { process }\end{array}$ & Danenas, P., Garsva, G. & 2009 & 18 & Lithuania \\
\hline $\begin{array}{l}\text { Variance-Covariance risk value } \\
\text { model for currency market }\end{array}$ & $\begin{array}{l}\text { Aniunas, P., } \\
\text { Nedzveckas, J., } \\
\text { Krušinskas, R. }\end{array}$ & 2009 & 13 & Lithuania \\
\hline $\begin{array}{l}\text { An analysis of dwelling market in } \\
\text { vilnius, Lithuania }\end{array}$ & $\begin{array}{l}\text { Ambrasas, G., } \\
\text { Stankeviius, D. }\end{array}$ & 2007 & 12 & Lithuania \\
\hline $\begin{array}{l}\text { Internationalisation and cross- } \\
\text { cultural business environment: } \\
\text { Modelling the training process of } \\
\text { expatriates }\end{array}$ & Grundey, D. & 2008 & 11 & Lithuania \\
\hline $\begin{array}{l}\text { A fuzzy analytic network process } \\
\text { method for risk prioritization in } \\
\text { freeway PPP projects: An Iranian } \\
\text { case study }\end{array}$ & $\begin{array}{l}\text { Valipour, A., Yahaya, } \\
\text { N., Md Noor, N., } \\
\text { Kildiene, S., Sarvari, } \\
\text { H., Mardani, A. }\end{array}$ & 2015 & 10 & Lithuania \\
\hline $\begin{array}{l}\text { Macroeconomic determinants of } \\
\text { loan portfolio credit risk in banks }\end{array}$ & Mileris, R. & 2012 & 10 & Lithuania \\
\hline
\end{tabular}

The authors' intention was also to extract from the search bibliometric data documents that are most used. Based on the request, the analysing tool revealed that data dates from 1904 until 2017 - a total of 2010 references.

The dominant authors were Zavadskas E.K. (27), Altman E.I. (19), Ginevičius R. (17), Mackevičius J. (16), Lai K.K. (13), Chan A.P.C. (12), Podvezko V. (12), 
Laitinen E.K. (11), and Wang S. (11); the number of other authors' documents did not exceed 10. Most documents were undefined by country/territory (1678), then followed United States (259), Lithuania (136), and United Kingdom (134); the number of other countries' documents did not exceed 100. In defined search, it is important to reveal most used articles that make an impact. Scopus does not have a special analysis tool extracting from search documents the bibliography that matches with all bibliometric data; therefore, data were analysed in Excel exported from Scopus database (Table 3). When working with data, some inconsistencies were seen in referenced documents (spelling mistakes in titles), which would to some point negatively impact the research field. Based on the obtained results, the authors provide top-10 documents with the number of sources used in the search (count) as well as a general citation review based on Scopus database.

Table 3. Mostly used documents (top-10) in the search, and citation overview of Scopus

\begin{tabular}{|c|c|c|c|c|}
\hline Authors & Title & Source title & Cited by & Count \\
\hline Altman, E.I. & $\begin{array}{c}\text { Financial ratios, } \\
\text { discriminant analysis and } \\
\text { the prediction of corporate } \\
\text { bankruptcy }\end{array}$ & $\begin{array}{l}\text { The Journal of } \\
\text { Finance }\end{array}$ & 3286 & 11 \\
\hline Ohlson, J.A. & $\begin{array}{l}\text { Financial ratios and the } \\
\text { probabilistic prediction of } \\
\text { bankruptcy }\end{array}$ & $\begin{array}{c}\text { Journal of } \\
\text { Accounting Research }\end{array}$ & 1554 & 9 \\
\hline Argenti, J. & $\begin{array}{l}\text { Corporate Collapse: The } \\
\text { Causes and Symptoms }\end{array}$ & $\begin{array}{c}\text { Corporate Collapse: } \\
\text { The Causes and } \\
\text { Symptoms } \\
\end{array}$ & 268 & 7 \\
\hline Argenti, J. & $\begin{array}{c}\text { Corporate Financial } \\
\text { Distress }\end{array}$ & $\begin{array}{l}\text { A Complete Guide to } \\
\text { Predicting, Avoiding, } \\
\text { and Dealing with } \\
\text { Bankruptcy }\end{array}$ & 6 & 7 \\
\hline $\begin{array}{l}\text { Dimitras, A.I., } \\
\text { Zanakis, S.H., } \\
\text { Zopounidis, C. }\end{array}$ & $\begin{array}{c}\text { A survey of business } \\
\text { failures with an emphasis } \\
\text { on prediction methods and } \\
\text { industrial applications }\end{array}$ & $\begin{array}{l}\text { European Journal of } \\
\text { Operational Research }\end{array}$ & 243 & 6 \\
\hline Kancerevyčius, G. & Finansai ir investicijos & $\begin{array}{l}\text { Finansai ir } \\
\text { investicijos }\end{array}$ & 4 & 6 \\
\hline Zmijewski, M.E. & $\begin{array}{l}\text { Methodological issues } \\
\text { related to the estimation of } \\
\text { financial distress } \\
\text { prediction models }\end{array}$ & $\begin{array}{c}\text { Journal of } \\
\text { Accounting Research }\end{array}$ & 847 & 4 \\
\hline Shumway, T. & $\begin{array}{c}\text { Forecasting bankruptcy } \\
\text { more accurately: A simple } \\
\text { hazard model }\end{array}$ & Journal of Business & 666 & 4 \\
\hline $\begin{array}{l}\text { Hambrick, D.C., } \\
\text { D'Aveni, R.A. }\end{array}$ & $\begin{array}{l}\text { Large corporate failures as } \\
\text { downward spirals }\end{array}$ & $\begin{array}{c}\text { Administrative } \\
\text { Science Quarterly }\end{array}$ & 367 & 4 \\
\hline Zavgren, C.V. & $\begin{array}{l}\text { Assessing the vulnerability } \\
\text { to failure of American } \\
\text { industrial firms: a logistic } \\
\text { analysis }\end{array}$ & $\begin{array}{c}\text { Journal of Business } \\
\text { Finance } \& \\
\text { Accounting }\end{array}$ & 193 & 4 \\
\hline
\end{tabular}




\section{CONCLUSION}

The research was led by an interdisciplinary problem field to reveal new aspects of financial risk assessment and represent key data that would contribute to researcher's studies. The authors concluded that bibliometric analysis could be used as a monitoring tool, getting insight of the number of documents; territory; authors; sources; citation overview, as well as measure impact of economic activity; therefore, the first research hypothesis was proved.

Documents started to appear for Baltic countries in 2005, which indicates author's science dynamics in financial risk assessment field. Graph pattern data showed that documents' publishing dynamics was closely related to enterprise death rates by the reference period for Latvia, Lithuania and Estonia, which evidences the second study hypothesis. It is important to note that in Lithuania, the publishing of documents started in 2005, whereas in Latvia and Estonia - in 2008 and 2010 respectively. Lithuania's quantitative dominance in number of scientific paper, authors, university and citation rates activity could be interpreted as the higher death rates compared to Latvia and Estonia. However, based on the research trend function where represented relation of documents per year to the number of enterprise deaths in the reference period divided by the number of enterprises active, the situation may change, consequently, death index in Lithuania and Latvia decreases, but in Estonia - increases. Publications by Lukason, O. (Estonia) indicates interest in risk assessment by reference period $2013-2017$, documents reveal occurrence and connections of various firm failures - exporting, manufacturing and small companies.

During the investigation, a pattern was seen showing that the risk of companies' death decreased during macroeconomic expansion. The global economic crisis started in 2008, and from 2009 until 2015, a recession can be seen for Baltic countries, consequently, not reaching/exceeding the 2009 death rates, which proves the pattern and the third hypothesis of the investigation.

In the paper, documents with high citation frequency are also represented. As revealed, the dominant country by citation rates is Lithuania. This could be explained by Lithuania's high enterprise death index; therefore, scientific work could be found valuable to prevent worse situation. Based on analyzed search, have been deducted documents that are mostly referenced as well as given a view of Scopus database general citation overview.

On the one hand, this research could be useful for future search directions as it gives retrospective analysis of the research topic/problem, therefore it confirms the importance and objectivity of field patterns and dynamics to get insight in the assessment of company's solvency. On the other hand, the authors would advise to vary the search by choosing more focused keywords and using more keywords when limiting the geographical territory. Analysed keywords such as risk assessment, risk management, risk analysis, and risk evaluation are closely connected with decision-making, which is why they appear in the search of different areas of economics and management. During the investigation, it was also concluded that there is no need of using additional analysis software (SciMat, 
Network Workbench Tool, CiteSpace) as Scopus analysis tools generate more accurate results.

For the analyzed geographical region, research revealed that the majority of scientific documents on the methods of assessing financial risks, namely, insolvency, liquidity and credit risks, could not be found in Scopus database: $62 \%$ of documents from Scopus and 64\% from Web of Science had different document titles, which proves the need of conducting research using online database of Web of Science. Moreover, while evaluating financial risk, it is wise to separately indicate the risks of fraud and abuse.

\section{REFERENCES}

Bornmann, L., \& Daniel, H. (2008). What do Citation Counts Measure? A Review of Studies on Citing Behaviour. Journal of Documentation, 64(1), 45-80. https://doi.org/10.1108/00220410810844150

Box, M. (2008). The Death of Firms: Exploring the Effects of Environment and Birth Cohort on Firm Survival in Sweden. Small Business Economics: an Entrepreneurship Journal, 31(4), 379-393. https://doi.org/10.1007/s11187-007-9061-2

Chen, H., Chiang, R.H.L., \& Storey, V.C. (2012). Business Intelligence and Analytics: from Big Data to big Impact. MIS Quarterly: Management Information Systems, 36(4), 1165-1188.

Chang, C.C., \& Ho, Y.S. (2010). Bibliometric Analysis of Financial Crisis Research. African Journal of

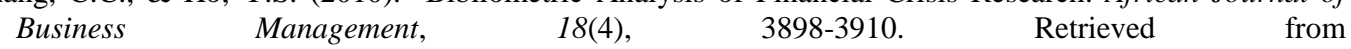
http://www.academicjournals.org/journal/AJBM/article-full-text-pdf/28464D616041

Elsvier (2017). Scopus: Access and use Support Center. How can I use an h-graph? Retrived from https://service.elsevier.com/app/answers/detail/a_id/11214/supporthub/scopus/related/1/

Eurostat (2017). Death rate: number of enterprise deaths in the reference period (t) divided by the number of enterprises active in t. Retrieved from https://goo.gl/o1jgJQ

Mishra, D., Gunasekaran, A., Childe, S. J., Papadopoulos, T., Dubey, R., Wamba, S. (2016). Vision, Applications and Future Challenges of Internet of Things: a Bibliometric Study of the Recent Literature. Industrial Management \& Data Systems, 116(7), 1331-1355. https://doi.org/10.1108/IMDS-11-2015-0478

Partridge, M.D., \& Rickman, D.S. (2002). Did the New Economy Vanquish the Regional Business Cycle? Contemporary Economic Policy, 20(4), 456-469. https://doi.org/10.1093/cep/20.4.456

Silva W., Kimura H., \& Sobreiro V. (2017). An Analysis of the Literature on Systemic Financial Risk: A Survey. Journal of Financial Stability, 28, 91-114. https://doi.org/10.1016/j.jfs.2016.12.004

Tatelbaum, C.M. (2014). The Domino Effect of Bankruptcy. Florida Trend, 57(4), 27-27.

Watts, R.J., \& Porter, A.L. (1997). Innovation Forecasting. Technological Forecasting and Social Change, 56(1), 14-47. https://doi.org/10.1016/s0040-1625(97)00050-4

\section{AUTHORS' SHORT BIOGRAPHIES}

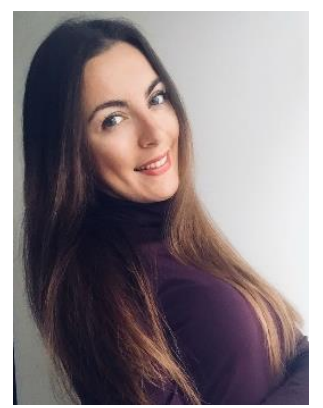

Natalia Scacun is a second-year student of the Master's study programme "Entrepreneurship and Management" at the Faculty of Engineering Economics and Management of Riga Technical University (RTU). She received the B.S. degree in the study programme "Entrepreneurship and Management" from RTU in 2016. Her professional background is accounting at "Rödl \& Partner" Ltd, and insurance at "AKA Insurance" Ltd. She is also a Finance Delivery Intern for the global international company "Stora Enso Eesti" AS in Estonia, where she is observing and interpreting financial data on everyday basis and applying best practices in financial management to make decisions. She seeks to react on economic challenges to answer appearing questions by finding the new trends and solutions in financial management field.

Address: Department of Innovation and Business Management, Faculty of Engineering Economics and Management, Riga Technical University, Riga, Latvia.

E-mail: natalia.scacun@edu.rtu.lv 


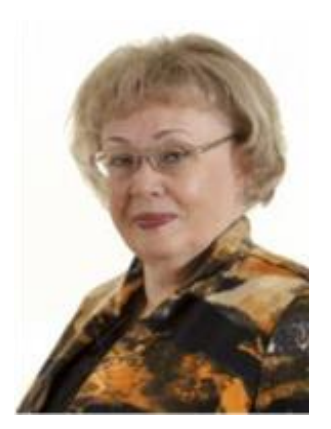

Irina Voronova, Dr. oec., is a Professor in risk management at the Faculty of Engineering Economics and Management of Riga Technical University (RTU). She holds the Ph.D. degree in economy from the Latvian Academy of Sciences and has more than a 40-year experience of scientific and pedagogical work. Her academic publications include articles in the International Journal of Banking Accounting and Finance, Scientific Proceedings of Riga Technical University, Proceedings of the International Congress of Actuaries, and others. I. Voronova is a Member of Latvian Actuarial Association. Her current research interests include risk management, insolvency risk forecasting, and decision making Address: Department of Innovation and Business Management, Faculty of Engineering Economics and Management, Riga Technical University, Riga, Latvia.

E-mail: irina.voronova@rtu.lv

ORCID iD: https://orcid.org/0000-0001-5117-7111 